\title{
Okul Yöneticilerinin Mizah Tarzları ile Yönetim Becerileri Arasındaki İlişki
}

\author{
DOI: 10.26466/opus.890396 \\ * \\ Püren Akçay * - Hilal Kevser Köprülü ** \\ * Dr. Öğr. Üyesi, İstanbul Aydın Üniversitesi, İstanbul/Türkiye \\ E-Posta: purenakcay@aydin.edu.tr. \\ ORCID: 0000-0002-0087-7561 \\ ** Öğretmen, Milli Eğitim Bakanlığı, İstanbul/Türkiye \\ E-Posta: ahmethilal12@hotmail.com \\ ORCID: $\underline{0000-0001-5604-7455}$
}

\begin{abstract}
Öz
Bu çalışmada, okul yöneticilerinin mizah tarzları ile yönetim becerileri arasındaki ilişkiyi boyut ve değişkenler çerçevesinde ayrıntıl bir şekilde ortaya koymak amaçlanmaktadır. Nicel araştırma yöntemlerinden ilişkisel tarama modelinin kullanıldığı araştırmanın örneklemini 2019-2020 e ğitim öğretim yılında Kocaeli İli, Karamürsel İlçesinde devlet okullarında görev yapmakta olan farklı branş ve kademeden, basit tesadüfi örnekleme yoluyla belirlenmiş 328 öğretmen oluşturmaktadır. Araştırmanın verileri, 'Kişisel Bilgi Formu', "Yönetim Becerileri Ölçeği" ve "Mizah Davranışları Ölçeği" kullanılarak elde edilmiştir. Okul yöneticisinin kullandıkları mizah tarzları ile yönetim beceri arasındaki ilişkinin çeşitli değgişkenler çerçevesinde ortaya konulmasını amaçlayan bu araştırma, samimi, açık, güvenilir ve ılımlı bir okul iklimi ve okul kültürü geliştirebilmek ve dolayısıyla okulun etkililiğini artıracak mizah tarzların ortaya koymak için önemlidir. Öğretmenlerin yaşı, kıdemi ve görev yaptıklar okul türlerinin okul yöneticilerinin algılanan mizah tarzlarında anlaml fark oluşturan değişkenler olduğu sonucunun yanında, reddedici mizah tarzı ile inisiyatif alma becerileri arasında negatif ve çift yönlü düşük düzeyde anlaml tespit edilen ilişki araştırmanın diğer önemli sonuçları arasında yer almaktadır.
\end{abstract}

Anahtar Kelimeler: Yönetim Becerileri, Yönetim Yeterlikleri, Mizah, Mizah Tarzı 


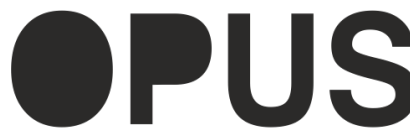

Uluslararası Toplum Araştırmaları Dergisi International Journal of Society Researches
E-ISSN: 2528-9535

Yıl Year. 11

Cilt Volume: 18

Sayı Issue: Yönetim ve Organizasyon Özel Sayısı

Temmuz July 2021

Makalenin Geliş Tarihi Received Date: 03/03/2021 Makalenin Kabul Tarihi Accepted Date: 14/06/2021

\title{
The Relationship between School Managers' Humor Styles and Management Skills
}

*

\begin{abstract}
In this study, it is aimed to reveal the relationship between school administrators' humor styles and management skills in detail within the framework of dimensions and variables. The sample of the study, in which the relational scanning model, one of the quantitative research methods, was used, consists of 328 teachers from different branches and levels working in state schools in Karamürsel, Kocaeli in the 2019-2020 academic year, determined by simple random sampling. The data of the study were obtained using 'Personal Information Form', 'Management Skills Scale' and 'Humor Behavior Scale'. It is important to develop a school climate and school culture and thus to reveal the humor styles that will increase the effectiveness of the school. Negative and bidirectional low-level significant relationship are among the other important results of the study.
\end{abstract}

Keywords: Management Skills, Management Competencies, Humor, Humor Style. 


\section{Giriş}

Okul yöneticileri, yönetsel becerilerini etkili şekilde kullanarak belirlenen amaçlara başarılı şekilde ulaşılmasından sorumludurlar (Edem, 1992). Yönetim becerileri, organizasyonun etkili bir şekilde yönetilmesi için yöneticilerin kişiliğindeki niteliklerdir (Kamble, 2011). Yönetimin başarılı olmasının temel unsuru, yöneticilerin yönetimsel becerilerini sadece bilgi, beceri, ustalık ve verimlilikle kullanmaları değil bu becerilerini geliştirmelerini de gerektirmektedir. Geleneksel yönetim becerileri sinıflandırmasında da yöneticilerin sahip olması gereken beceriler üç kategoride toplamıştır. Bunlar teknik, insani ve kavramsal becerileridir. Quast ve Hazucha (1992, s.203) ise yönetim becerilerini beş boyutta tanımlamışlardır. Bunlar, inisiyatif alma becerileri, sorumluluk alma becerileri, teknik beceriler, nitelik becerileri ve diğer beceriler. İnsiyatif alma becerileri, iletişimi, insan ilişkilerini, çatışma yönetimini ve çalışanları motive etme gibi konuları; sorumluluk alma becerileri, planlama, örgütsel ve kişisel organizasyon, zaman yönetimi, enformasyon, liderlik, etkileme, denetleme ve atama konularını; teknik beceriler, yazılı iletişim yollarını, finansman ve nicel, mesleki bilgileri ve teknik bilgileri; nitelik becerileri, kişisel motivasyon, nitelikli çalışma, öğrenci başarısı ve bilgilendirmeye ilişkin konuları; diğer beceriler ise sözel iletişimler, problem analizi ve karar alma konularını içermektedir.

Yöneticinin yönetim becerilerinin yanında mizah tarzlarının da okul yönetiminde önemli bir yeri olduğu düşünülmektedir. Alanyazında mizahın okul yönetiminde önemli bir faktör olduğu sonucuna ulaşan birçok araştırma olduğu tespit edilmiştir (Akyol, 2016; Alan ve Şen, 2016; Ayduğ, Himmetoğlu ve Bayrak, 2018; Cross, 1989; Özdemir ve Recepoğlu, 2010; Recepoğlu E., 2011; Williams ve Clouse, 1991; Yılmaz, 2011; Ziegler, Boardman ve Thomas, 1985). Alanyazında okul yöneticilerinin mizah tarzlarının okul yönetim sürecini kolaylaştırıcı bir unsur olduğu ve olumsuzlukları olumluya dönüştürdüğü, motivasyon ve birlikte çalışma isteğini arttırdığı görülmektedir (Çelikten ve Çelikten, 2018).

$\mathrm{Bu}$ araştırma kapsamında mizah tarzları incelenirken Cemaloğlu, Recepoğlu, Şahin, Daşcı ve Köktürk'ün (2012) geliştirdiği mizah tarzları 
esas alınmıştır. Bu mizah tarzları, alaycı, üretici, onaylayıcı, reddedici mizah tarzı ve mizahi olmayan tarzlardır.

Alaycı mizah tarzı, diğer insanlara sataşmaya, onlarla herhangi bir nedenle dalga geçmeye ve onları zor durumda bırakmaya yönelik olarak kullanılan mizah tarzını ifade etmektedir (Çelik, 2014). Alaycı mizah tarzı diğer insanları rencide edici ve aşağılayıcı, onların duygularını olumsuz etkileyen mizah tarzı olarak ifade edilmektedir. Üretici mizah tarzınını benimseyenler, bulundukları ortamında mizahi yönü olan bir durum yaratmakta ve bu durumu diğer insanlarla paylaşmaktadır. Bu bağlamda üretici mizah tarzına sahip olan bireyler, güldüren, eğlendiren ve çalışma ortamındaki sinerjiyi canlı tutan bireyler olarak tanımlanabilir. Aynı zamanda mizah üretebilen kişilerin bulundukları ortamda sevilen ve beraber çalışmaktan keyif alınan kişiler olduğu söylenebilir. Onaylayıcı mizah tarzı, mizaha karşı önyargı ve olumsuz bir bakış açısının olmadığı mizah tarzıdır. Onaylayıcı mizah tarzını benimseyen bireyler, mizaha sempati duyar, kendilerine espri yapılmasından rahatsız olmazlar. Reddedici mizah tarzına sahip kişiler, mizaha olumsuz bakış açısı ile yaklaşır ve mizahi tutum, davranış ve sözleri kabul etmezler. Mizahı reddeden bu bireyler, mizah yapan insanlara şüphe duymakta ve onlara karşı önyargılı davranmaktadır. Mizahi olmayan davranış tarzı, mizahı sözlerinde ve davranışlarında yok denecek kadar az kullanan, şaka ve espri yapmayı tercih etmeyen ve yapılan bir espri karşısında gülme davranışı göstermekten kaçınan bireylerin sahip olduğu davranış tarzı olarak ifade edilmektedir (Cemaoğlu, vd, 2012).

$\mathrm{Bu}$ kuramsal çerçeve bağlamında okul yöneticisinin kullandıkları mizah tarzları ile yönetim becerileri arasındaki ilişkinin çeşitli değişkenler çerçevesinde ortaya konulmasını amaçlayan bu araştırma, samimi, açık, güvenilir ve 1 lımlı bir okul iklimi ve okul kültürü geliştirebilmek ve dolayısıyla okulun etkililiğini artıracak mizah tarzlarını ortaya koymak için önemlidir. Vickers (1994) da okul yöneticilerinin mizah tarzları ile yönetim becerileri arasında anlamlı bir ilişki olduğu sonucuna ulaşmıştır.

Doğru mizahi davranış tarzı ile desteklenecek olumlu bir okul kültürü ve okul ikliminin, okulun bütün paydaşlarının verimliliğini artırırken aynı zamanda okul etkililiğini de artıracağı açıtır. 


\section{Araştırmanın Amacı}

Yukarıda açıklanan kuramsal çerçeve bağlamında bu araştırmanın amac1, öğretmen görüssleri doğrultusunda okul yöneticilerinin kullandıkları mizah tarzları ile yönetim becerileri arasındaki ilişkiyi boyut ve değişkenler çerçevesinde ortaya koymaktır. Bu ana amaçtan hareketle, araştırmada cevap aranan sorular şunlardır:

- Öğretmenlerin, okul müdürlerinin algılanan mizah tarzları ile yönetim becerileri ne düzeydedir?

- Öğretmenlerin, okul müdürlerinin mizah tarzları değişkenlere göre anlamlı farklılık göstermekte midir?

- Öğretmenlerin okul müdürlerinin mizah tarzları ile yönetim becerilerine ilişkin algıları arasında anlamlı bir ilişki var mıdır?

\section{Yöntem}

$\mathrm{Bu}$ bölümde araştırmanın modeli, evren ve örneklemi, veri toplama araçları ile verilerin analizi ile ilgili bilgiler yer almaktadır.

\section{Araştırmanın Modeli}

$\mathrm{Bu}$ araştırmada nicel araştırma yöntemlerinden ilişkisel tarama modeli kullanılmıştır. İlişkisel tarama yöntemi, iki ya da daha fazla değişkeni inceleyerek bu değişkenlerin beraberce değişip değişmediğini, değişme yaşanıyorsa bunun ne şekilde olduğunu bulmayı hedefleyen bir yöntemdir (Büyüköztürk, vd. 2012; Karasar, 2012).

\section{Evren ve Örneklem}

Araştırmanın evrenini Kocaeli İli, Karamürsel ilçesinde 2020-2021 eğitim öğretim yılında devlet okullarında görev yapan öğretmenler oluşturmaktadır. Araştırmanın örneklemini 2019-2020 eğitim öğretim yılında, Karamürsel İlçesinde devlet okullarında görev yapmakta olan farklı branş ve kademeden basit tesadüfi örnekleme yöntemi ile belirlenen 328 öğretmen oluşturmaktadır. 


\section{Veri Toplama Araçları}

Araştırmada veri toplama aracı olarak 'Sosyo-demografik Bilgi Formu', 'Yönetim Becerileri Ölçeği' (Şekerci, 2006) ve 'Mizah Davranışları Ölçeği' (Cemaoloğlu, Recepoğlu, Şahin ve E. ve Köktürk, 2012) kullanılmıştır.

Yönetim Becerileri Ölçeği: Araştırmada Quast ve Hazucha tarafından geliştirilen ve Şekerci'nin (2006) Türkçeye uyarladığ1, "Yönetim Becerileri Ölçeği" kullanılmıştır. Yönetim becerileri ölçekte insiyatif alma, sorumluluk alma, teknik beceriler, diğer beceriler ve nitelik beceriler şeklinde beş alt boyut ve 34 maddede gruplandırılmıştır. Ölçek maddeleri hiç katılmıyorum, katılmıyorum, fikrim yok, katılıyorum, tamamen katılıyorum şeklinde, beşli likert tipinde derecelendirilerek oluşturulmuştur. Şekerci'nin (2006) araştırmasındaki geçerlik ve güvenirlik çalışmalarında, iç tutarlılık kat sayısı Cronbach Alpha değeri .95 ve ölçeğin alt boyutlarının iç tutarlılık katsayıları, inisiyatif alma .87, sorumluluk alma .87 , teknik yeterlikler .69 ve diğer beceriler .94 olarak elde edilmiştir. Teknik yeterlikler alt boyutunun değeri diğerlerine göre biraz düşük olarak bulunmakla birlikte kabul edilebilir bir düzeyde olduğu görülmüştür.

Mizah Davranışlarn Ölçeği Ölçeği: Araştırmada kullanılan bir diğer ölçek, Cemaoloğlu, Recepoğlu, Şahin ve Köktürk (2012) tarafından geliştirilen "Mizah Davranışları Ölçeği” dir. Mizah Davranışları Ölçeği, beşli likert tipi olup, 30 maddeden oluşmaktadır. Ölçek, okul müdürlerinin mizah davranışlarının alaycı, üretici sosyal, onaylayıcı, reddedici ve mizahi olmayan davranış olarak beş boyutta yapılandırılmıştır. Alaycı Mizah için .943, Üretici Sosyal Mizah için .923, Onaylayıcı Mizah için .864, Reddedici Mizah için .855 ve Kullanılmayan Mizah için .895 ve ölçeğin tamamının Cronbach Alfa değeri 0.91 elde edilmiştir. Bu veriler ölçeğin yüksek derecede güvenilir olduğunu göstermektedir. 


\section{Verilerin Analizi}

Veri toplama araçları ile katılımcılardan toplanan veriler SPSS 25 istatistik analiz programı aracılığıyla analiz edilmiştir. Verilerin normal dağılımının kontrolü için, basıklık ve çarpıklık değerleri esas alınmıştır. $\mathrm{Bu}$ veriler dikkate alındığında dağılımın normallik gösterdiği kabul edilerek yönetim becerileri ölçeğinden elde edilen verilerin analizinde parametrik, mizah davranışları ölçeğinden elde edilen verilerin analizinde ise dağılım normallik göstermediğinden non-parametrik testlerin uygulanmasına karar verilmiştir. Yönetim becerileri ölçeğine ilişkin veriler normal dağılım gösterdiği için, aritmetik ortalama ve standart sapma değerleri dikkate alınırken, mizah davranışları ölçeğine ilişkin veriler normal dağılım göstermediğinden, çeyreklik aralığı ve ortanca değerleri dikkate alınmıştır. Yönetim becerileri ölçeğinin verileri t-testi ve one way ANOVA testi ile analiz edilmiştir. Mizah davranışları ölçeğine ilişkin verilerin analizinde ise Mann Whitney U Testi ve Kruskal Wallis H Testi uygulanmıştır. Anlamlı farklılığın hangi ikili gruplar arasında olduğunu bulmak için gruplar arasında Mann Whitney U Testi yapılarak ikili karşılaştırmaların anlamlılık düzeyi yorumlanmıştır. Son olarak okul müdürlerinin mizah tarzları ve yönetim becerileri arasındaki ilişki düzeyinin belirlenmesinde pearson korelasyon analizinden istifade edilmiştir. Yapılan analizlerde anlamlılık düzeyi $\mathrm{p}<.05$ olarak değerlendirmeler yapılmıştır.

\section{Bulgular ve Yorumlar}

Bulgular ve bulgulara ait yorumlar, araştırma sorularının verilişindeki sıraya uygun olarak tablolaştırılmış ve düzenlenmiştir.

\section{Okul Yöneticilerinin Algılanan Mizahi Tarzlarına ve Yönetim Becerileri Ilişkin Bulgular}

Mizah davranışları ölçeğinin alt boyutlarına ilişkin puan ortalamaları incelendiğinde, onaylayıcı mizah tarzının (Xort $=3,80$ ) diğer mizah tarzlarından yüksek düzeyde algılandığı görülmektedir. Bunun yanı sıra alaycı mizah tarının çok düşük $($ Xort $=1,00)$, üretici mizah tarzının 
orta (Xort $=3,33)$, reddedici mizah tarzının çok düşük (Xort $=1,40)$ ve mizahi olmayan tarzın çok düşük $($ Xort $=1,66)$ düzeyde algılandığ1 görülmüştür. Ayduğ, Himmetoğlu ve Bayrak'ın (2018) araştırmasında da öğretmenler, okul müdürlerinin mizah tarzını, en fazla motive edici mizah ve sorun çözücü mizah olarak tanımlamışlardır. Motive edici mizah, okul müdürünün mizah tarzının, öğretmenleri mutlu etmesi, motive etmesi, olumlu enerji vermesi, iş yaşamını renklendirmesi gibi nedenlerde, iletişimde bulunanlara zarar vermeden ilişkileri geliştirmeye yönelik mizah türü olan onaylayıcı mizah ile benzerlik göstermektedir (Martin vd., 2003). Mizahı onaylayan okul yöneticileri, okul içinde sosyal ilişkileri koruyucu ve destekleyici davranış göstererek okul iklimini de olumlu etkilemiş olacaktır. Reynolds ve arkadaşları (2000), okul iklimine ilişkin unsurların, okul etkililiğinin önemli bir belirleyicisi olduğunu tespit etmiştir. Şenel ve Buluç'un (2016) araştırmasında da, okul etkililiği ile mesleki öğretmen davranışları, destekleyici müdür davranışları, samimi öğretmen davranışları ve yönlendirici müdür davranışları arasında pozitif orta düzeyde anlamlı bir ilişki olduğu görülmektedir. Pawlas (1997), sağlam, olumlu ve etkili okul kültürünün temel ögeleri ile ortak değerler, kullanılan mizah, hikaye anlatımı, iletişim ağı, ritüeller, seremoni ve meslektaşları ilişkilendirmektedir. Bu gibi bir okul kültürü, okul ve paydaşlarına olumlu çıktılar sağlayacağı açıktır.

Araştırmada öğretmen görüşlerine göre okul yöneticilerinin yönetim beceri düzeylerinin yüksek düzeyde olduğu sonucuna ulaşılmıştır. Bununla beraber öğretmen görüşlerine göre okul yöneticilerinin en yüksek yönetim beceri düzeyinin inisiyatif alma becerilerine ait olduğunu $(\bar{x}=4,05)$ görülmektedir. Aynı zamanda okul yöneticilerinin sorumluluk alma becerilerinin $(\bar{x}=4,01)$, teknik becerilerinin $(\bar{x}=3,96)$, diğer becerilerin $(\bar{x}=3,65)$ ve nitelik becerilerinin $(\bar{x}=3,88)$ düzeylerinin de yüksek düzeyde algılandığı görülmektedir. Quast ve Hazucha'a göre (1992, s.203) yönetim becerilerinden insiyatif alma becerileri, çalışanlarla ilişkiler, çatışma yönetimi ve çalışanları motive etme gibi hususlarda kendini göstermektedir. Yönetim eylemlerinde inisiyatif alma, stresi (Searle, 2008) ve tükenmişliği (Xue ve Wang, 2009) azaltmasının yanında, yöneticilerin ve çalışanların iyi olma hali (Hahn, Frese, Binnewies ve Schmitt, 2011; Taris ve Wielenga-Meier, 2010) ile iş doyumunu (Gamboa, Gracia, Ripoll ve Peiro, 2009) artırdığ1 yönünde bulgular elde edilen 
araştırmalar çerçevesinde okul yöneticilerinin inisiyatif alma becerileri düzeylerinin yüksek olmasının okul yöneticisinin etkililiğini artıracağını ve okulun hedeflerine ulaşmasında katkısı olacağı söylenebilir.

\section{Okul Yöneticilerinin Mizah Tarzlarının Değişkenlere Göre İncelenmesi}

Okul yöneticilerinin algılanan mizah tarzları cinsiyet, eğitim durumu, medeni durum, yaş, gelir seviyesi, çocuk sayısı, okul türü ve kıdem değişkenlerine göre incelenmiştir.

Cinsiyete Göre Okul Yöneticilerinin Mizah Tarzlarına İlişkin Bulgular: Tablo 1'de cinsiyet değişkenine göre okul yöneticilerinin mizahi davranış düzeylerine ilişkin Mann-Whitney $U$ testi sonuçları verilmiştir.

Tablo 1. Cinsiyetlerine Göre Okul Yöneticilerinin Algılanan Mizah Tarzları

\begin{tabular}{lllllll}
\hline Boyut & Cinsiyet & $\mathbf{n}$ & Sira Ortalaması & Sira Toplamı & U & p \\
\hline Alayc1 & Kadın & 177 & 164.19 & 29062.00 & 13309.000 & .941 \\
& Erkek & 151 & 164.86 & 24894.00 & & \\
\hline Üretici & Kadın & 177 & 165.89 & 29362.50 & 13117.500 & .774 \\
& Erkek & 151 & 162.87 & 24593.50 & & \\
\hline Onaylayıc1 & Kadın & 177 & 165.15 & 29232.00 & 13248.000 & .892 \\
& Erkek & 151 & 163.74 & 24724.00 & & \\
\hline Reddedici & Kadın & 177 & 160.73 & 28450.00 & 12697.000 & .418 \\
& Erkek & 151 & 168.91 & 25506.00 & & \\
\hline Mizah & Kadın & 177 & 169.07 & 29925.50 & 12554.500 & .336 \\
Olmayan & Erkek & 151 & 159.14 & 24030.50 & & \\
\hline
\end{tabular}

Tabloya göre; öğretmenlerin cinsiyetlerine göre yöneticilerin mizah tarzlarına ilişkin algılarında anlamlı farklılık bulunamamıştır. Bu bulguya göre cinsiyet değişkeninin algılanan mizah tarzına etkili olmadığı, bir diğer ifadeyle kadın veya erkek öğretmenlerin, okul yöneticilerinin algılanan mizah tarzları konusunda benzer görüşlere sahip oldukları söylenebilir. 
Ĕ̆itim Durumuna Göre Okul Yöneticilerinin Algılanan Mizah Tarzına İlişkin Bulgular:

Tablo 2'de eğitim durumu değişkenine göre okul yöneticilerinin mizah davranış düzeylerine ilişkin Mann-Whitney U sonuçları verilmiştir.

Tablo 2. Ĕ̆itim Durumuna Göre Okul Yöneticilerinin Algılanan Mizah Tarzları

\begin{tabular}{lllllll}
\hline Boyut & Eğitim Durumu & $\mathbf{n}$ & $\begin{array}{l}\text { Sira } \\
\text { Ortalaması }\end{array}$ & $\begin{array}{l}\text { Sira } \\
\text { Toplamı }\end{array}$ & U & p \\
\hline Alayc1 & Lisans & 308 & 164.77 & 50748.00 & 2998.000 & .818 \\
& Yüksek Lisans & 20 & 160.40 & 3208.00 & & .586 \\
\hline Üretici & Lisans & 308 & 165.23 & 50889.50 & 2856.500 & \\
& Yüksek Lisans & 20 & 153.32 & 3066.50 & & .864 \\
\hline Onaylayıc1 & Lisans & 308 & 164.27 & 50596.00 & 3010.000 & .139 \\
& Yüksek Lisans & 20 & 168.00 & 3360.00 & & 2496.000 \\
\hline Reddedici & Lisans & 308 & 162.60 & 50082.00 & & .331 \\
& Yüksek Lisans & 20 & 193.70 & 3874.00 & 2688.000 & \\
\hline Mizah & Lisans & 308 & 163.23 & 50274.00 & & \\
Olmayan & Yüksek Lisans & 20 & 184.10 & 3682.00 & & \\
\hline
\end{tabular}

Tabloya göre; öğretmenlerin eğitim durumuna göre okul yöneticilerinin mizah tarzlarına ilişkin algılarında anlamlı farklılık bulunamamıştır. Bu bulguya göre eğitim durumu değişkeninin algılanan mizah tarzına etkili olmadığı, bir diğer ifadeyle lisans veya yüksek lisans mezunu öğretmenlerin, okul yöneticilerinin algılanan mizah tarzları konusunda benzer görüşlere sahip oldukları söylenebilir.

\section{Medeni Duruma Göre Okul Yöneticilerinin Algılanan Mizah Tarzına İlişkin Bulgular:}

Tablo 3'te medeni durum değişkenine göre okul yöneticilerinin mizah davranış düzeylerine ilişkin Mann-Whitney U sonuçları verilmiştir.

Tabloya göre; öğretmenlerin medeni durumuna göre okul yöneticilerinin mizah tarzlarına ilişkin algılarında anlamlı farklılık bulunamamıştır. Bu bulguya göre medeni durum değişkeninin algılanan mizah tarzına etkili olmadığg söylenebilir. Bir diğer ifadeyle belirtmek gerekirse, bekar veya evli olan öğretmenler, okul yöneticilerinin algılanan mizah tarzları konusunda benzer görüşlere sahiptirler. 
Tablo 3. Medeni Duruma Göre Okul Yöneticilerinin Algılanan Mizah Tarzları

\begin{tabular}{lllllll}
\hline Boyut & Medeni Durum & $\mathbf{n}$ & Sira Ortalamasi & Sira Toplamı & U & p \\
\hline Alayc1 & Evli & 277 & 165.88 & 45950.00 & 6680.000 & .477 \\
& Bekar & 51 & 156.98 & 8006.00 & & \\
\hline Üretici & Evli & 277 & 164.10 & 45455.00 & 6952.000 & .858 \\
& Bekar & 51 & 166.69 & 8501.00 & & \\
\hline Onaylayıc1 & Evli & 277 & 166.37 & 46085.50 & 6544.500 & .403 \\
& Bekar & 51 & 154.32 & 7870.50 & & \\
\hline \multirow{2}{*}{ Reddedici } & Evli & 277 & 164.68 & 45617.50 & 7012.500 & .932 \\
& Bekar & 51 & 163.50 & 8338.50 & & \\
\hline Mizah Olmayan & Evli & 277 & 165.63 & 45880.00 & 6750.000 & .608 \\
& Bekar & 51 & 158.35 & 8076.00 & & \\
\hline
\end{tabular}

\section{Yaşa Göre Okul Yöneticilerinin Algılanan Mizah Tarzına İlişkin Bulgular}

Tablo 4'te yaş değişkenine göre okul yöneticilerinin mizah davranış düzeylerine ilişkin Kruskal Wallis testi sonuçları verilmiştir.

Tablo 4. Yaşa Göre Okul Yöneticilerinin Algılanan Mizah Tarzları

\begin{tabular}{|c|c|c|c|c|c|c|}
\hline Boyut & Yaş & $\mathrm{n}$ & Sira Ortalaması & sd & $X^{2}$ & $\mathrm{p}$ \\
\hline \multirow[t]{4}{*}{ Alaycı } & $20-29$ & 13 & 178.92 & .76537 & 3.718 & .294 \\
\hline & $30-39$ & 96 & 169.97 & & & \\
\hline & $40-49$ & 165 & 156.17 & & & \\
\hline & 50 ve üstü & 54 & 176.76 & & & \\
\hline \multirow[t]{4}{*}{ Üretici } & $20-29$ & 13 & 155.58 & 1.08763 & .557 & .906 \\
\hline & $30-39$ & 96 & 160.20 & & & \\
\hline & $40-49$ & 165 & 168.09 & & & \\
\hline & 50 ve üstü & 54 & 163.32 & & & \\
\hline \multirow[t]{4}{*}{ Onaylayıcı } & $20-29$ & 13 & 79.08 & .94907 & 18.857 & $.000^{*}$ \\
\hline & $30-39$ & 96 & 148.02 & & & \\
\hline & $40-49$ & 165 & 181.46 & & & \\
\hline & 50 ve üstü & 54 & 162.53 & & & \\
\hline \multirow[t]{4}{*}{ Reddedici } & $20-29$ & 13 & 211.42 & .83792 & 9.610 & $.022^{*}$ \\
\hline & $30-39$ & 96 & 176.73 & & & \\
\hline & $40-49$ & 165 & 150.58 & & & \\
\hline & 50 ve üstü & 54 & 174.00 & & & \\
\hline \multirow[t]{4}{*}{ Mizah Olmayan } & $20-29$ & 13 & 176.15 & .94505 & .926 & .819 \\
\hline & $30-39$ & 96 & 170.34 & & & \\
\hline & $40-49$ & 165 & 160.25 & & & \\
\hline & 50 ve üstü & 54 & 164.31 & & & \\
\hline
\end{tabular}


Tablo 4'teki bulgulara göre, öğretmenlerin yaşına göre okul yöneticilerinin onaylayıcı ve reddedici mizah tarzlarındaki alg1 düzeyinde anlamlı farklılık bulunmakta; alaycı, üretici ve mizah olmayan mizh tarzlarında anlamlı farklılık bulunmamaktadır $(\mathrm{p}<0,05)$. Hangi gruplar arasında anlamlı farklılık olduğunu belirlemek için gruplar arasında Mann Whitney $U$ testi uygulanmıştır. Tablo 5'te onaylayıcı ve reddedici mizah tarzlarına İlişkin Mann-Whitney U Testi Sonuçları verilmiştir.

Tablo 5. Yaş Değişkenine Göre Onaylayıcı ve Reddedici Mizah Tarzlarına İlişkin Mann-Whitney U Testi Sonuçlan

\begin{tabular}{lllllll}
\hline Boyutlar & $\begin{array}{l}\text { Gelir } \\
\text { Seviyesi }\end{array}$ & $\mathbf{n}$ & $\begin{array}{l}\text { Sira } \\
\text { Ortalaması }\end{array}$ & Sira Toplamı & U & p \\
\hline Onaylayıc1 & $20-29$ & 13 & 35.31 & 459.00 & 368.000 & $.016^{*}$ \\
Mizah Tarz1 & $30-39$ & 96 & 57.67 & 5536.00 & & \\
& $20-29$ & 13 & 38.62 & 502.00 & 411.000 & $.000^{*}$ \\
& $40-49$ & 165 & 93.51 & 15429.00 & & \\
& $20-29$ & 13 & 19.15 & 249.00 & 158.000 & $.002^{*}$ \\
& $50-+$ & 54 & 37.57 & 2029.00 & & \\
& $30-39$ & 96 & 114.35 & 10978.00 & 6322.000 & $.006^{*}$ \\
& $40-49$ & 165 & 140.68 & 23213.00 & & \\
\hline Reddedici & $20-29$ & 13 & 120.31 & 1564.00 & 672.000 & $.018^{*}$ \\
Mizah Tarz1 & $40-49$ & 165 & 87.07 & 14367.00 & & \\
& $30-39$ & 96 & 144.03 & 13827.00 & 6669.000 & $.026^{*}$ \\
& $40-49$ & 165 & 123.42 & 20364.00 & & \\
\hline
\end{tabular}

Tablo 5'te belirtilen sıra ortalamaları dikkate alındığında 20-29 yaş grubundaki öğretmenlerin diğer bütün yaş gruplarının ortalamalarına oranla okul yöneticilerinin mizah tarzlarını daha düşük düzeyde onaylayıcı algıladıkları görülmektedir. Reddedici mizah tarzında anlamlı farklılık yaratan grupların sıra ortalamaları incelendiğinde ise, 40-49 yaş grubundaki öğretmenlerin kendilerinden küçük yaş gruplarındaki öğretmenlere oranla okul yöneticilerinin mizah tarzlarını daha düşük oranda reddedici algıladıkları görülmektedir. Bu iki bulgu, 20-29 yaş grubundaki öğretmenlerin okul yöneticilerinin mizah tarzlarını daha fazla reddedici tarzda algıladıkları ve 40-49 yaş grubu öğretmenlerin okul yöneticilerinin mizah tarzlarını daha fazla onaylayıcı mizah tarzında algıladıkları şeklinde yorumlanabilir. 
Benzer şekilde, Recepoğlu (2011), Recepoğlu ve Özdemir (2010), Recepoğlu ve Özdemir (2012) araştırmalarında okul müdürlerinin mizah tarzları, öğretmenlerin yaşlarına göre anlamlı farklılık göstermektedir. $\mathrm{Bu}$ araştırmalarda, 51 yaş ve üzerindeki öğretmenlerin mizah kullanım puanları en yüksek düzeydedir. Dinç ve Cemaloğlu (2018) da öğretmenlerin yaşları ilerledikçe okul yöneticilerinin algılanan mizah tarzlarını daha fazla alaycı buldukları sonucuna ulaşmıştır. Yılmaz (2011) da araştırmasında kendini geliştirici mizah tarzında yaşı 41 ve üstünde olan okul yöneticilerinin mizah tarzının daha olumlu olduğu sonucuna ulaşmıştır. Yaşı daha büyük olan öğretmenlerin mesleki deneyimi ve yöneticilerle daha fazla sürede çalışmış olması beklenen bir durumdur. Bu iletişim kanallarının genç öğretmenlere göre daha fazla sürede kullanılmış olması ile ileri yaştaki öğretmenlerin okul yöneticilerinin mizah tarzlarını daha onaylayıcı algıladı̆̆ı söylenebilir. Mesleğin başlarında genç yaştaki öğretmenlerin okul yöneticileri ile arasında kurulan yeni iletişim şekli gereği, okul yöneticisinin mizah tarzının daha fazla reddedici tarzda algılanması normal karşılanabilir. $\mathrm{Bu}$ durumun yöneticilerin genç öğretmenler üzerindeki otorite oluşturabilme ve disiplin kurallarını uygulayabilme isteğinden de kaynaklanabileceği söylenebilir.

\section{Gelir Seviyesine Göre Okul Yöneticilerinin Algılanan Mizah Tarzına İlişkin Bulgular}

Tablo 6'da gelir seviyesi değişkenine göre okul yöneticilerinin mizah davranış düzeylerine ilişkin Mann-Whitney U sonuçları verilmiştir.

Tabloya göre; öğretmenlerin gelir seviyesine göre okul yöneticilerinin mizah tarzlarına ilişkin algılarında anlamlı farklılık bulunmamıştır. $\mathrm{Bu}$ bulguya göre gelir seviyesi değişkeninin algılanan mizah tarzına etkili olmadığı, bir diğer ifadeyle gelir seviyesi 10.000 TL ve altında veya $10.000 \mathrm{TL}$ üstünde olan öğretmenlerin, okul yöneticilerinin algılanan mizah tarzları konusunda benzer görüşlere sahip oldukları söylenebilir. 
Tablo 6. Medeni Duruma Göre Okul Yöneticilerinin Algılanan Mizah Tarzlar

\begin{tabular}{|c|c|c|c|c|c|c|}
\hline Boyut & $\begin{array}{l}\text { Gelir } \\
\text { Seviyesi }\end{array}$ & $\mathbf{n}$ & $\begin{array}{l}\text { Sira } \\
\text { Ortalaması }\end{array}$ & Sira Toplamı & $\mathbf{U}$ & $\mathrm{p}$ \\
\hline \multirow[t]{2}{*}{ Alayc1 } & 10.000 alt & 50 & 152.93 & 7646.50 & 6371.500 & .280 \\
\hline & 10.000 üst & 278 & 166.58 & 46309.50 & & \\
\hline \multirow[t]{2}{*}{ Üretici } & 10.000 alt & 50 & 167.57 & 8378.50 & 6796.500 & .804 \\
\hline & 10.000 üst & 278 & 163.95 & 45577.50 & & \\
\hline \multirow[t]{2}{*}{ Onaylayıcı } & 10.000 alt & 50 & 141.64 & 7082.00 & 5807.000 & .063 \\
\hline & 10.000 üst & 278 & 168.61 & 46874.00 & & \\
\hline \multirow[t]{2}{*}{ Reddedici } & 10.000 alt & 50 & 161.51 & 8075.50 & 6800.500 & .801 \\
\hline & 10.000 üst & 278 & 165.04 & 45880.50 & & \\
\hline Mizah & 10.000 alt & 50 & 145.43 & 7271.50 & 5996.500 & .116 \\
\hline Olmayan & 10.000 üst & 278 & 167.93 & 46684.50 & & \\
\hline
\end{tabular}

\section{Çocuk Sayısına Göre Okul Yöneticilerinin Algılanan Mizah Tarzına İlişkin Bulgular}

Tablo 7'de çocuk sayısı değişkenine göre okul yöneticilerinin mizah davranış düzeylerine ilişkin Kruskal Wallis testi sonuçları verilmiştir.

Tablo 7. Çocuk Sayısına Göre Okul Yöneticilerinin Algılanan Mizah Tarzları

\begin{tabular}{|c|c|c|c|c|c|c|}
\hline Boyut & Çocuk Sayısı & $\mathbf{n}$ & Sira Ortalaması & sd & $\mathrm{X}^{2}$ & $\mathrm{p}$ \\
\hline \multirow[t]{4}{*}{ Alayc1 } & Yok & 63 & 153.75 & .76537 & 2.629 & .452 \\
\hline & 1 Çocuk & 78 & 159.86 & & & \\
\hline & 2 Çocuk & 143 & 167.83 & & & \\
\hline & 3 ve fazla & 44 & 177.32 & & & \\
\hline \multirow[t]{4}{*}{ Üretici } & Yok & 63 & 161.94 & 1.08763 & .179 & .981 \\
\hline & 1 Çocuk & 78 & 167.54 & & & \\
\hline & 2 Çocuk & 143 & 164.95 & & & \\
\hline & 3 ve fazla & 44 & 161.33 & & & \\
\hline \multirow[t]{4}{*}{ Onaylayıcı } & Yok & 63 & 154.36 & .94907 & 2.083 & .555 \\
\hline & 1 Çocuk & 78 & 158.03 & & & \\
\hline & 2 Çocuk & 143 & 172.38 & & & \\
\hline & 3 ve fazla & 44 & 164.89 & & & \\
\hline \multirow[t]{4}{*}{ Reddedici } & Yok & 63 & 156.46 & .83792 & .804 & .849 \\
\hline & 1 Çocuk & 78 & 162.60 & & & \\
\hline & 2 Çocuk & 143 & 167.76 & & & \\
\hline & 3 ve fazla & 44 & 168.77 & & & \\
\hline Mizah & Yok & 63 & 162.56 & .94505 & 1.862 & .602 \\
\hline \multirow[t]{3}{*}{ Olmayan } & 1 Çocuk & 78 & 156.74 & & & \\
\hline & 2 Çocuk & 143 & 172.10 & & & \\
\hline & 3 ve fazla & 44 & 156.33 & & & \\
\hline
\end{tabular}


Tabloya göre; öğretmenlerin çocuk sayısına göre okul yöneticilerinin mizah tarzlarına ilişkin algılarında anlamlı farklılık bulunamamıştır. Bu bulguya göre çocuk sayısı değişkeninin algılanan mizah tarzına etkili olmadığı, bir diğer ifadeyle çocuğu olmayan, tek çocuğu olan, iki çocuğu olan ve üç ve fazla çocuğu olan öğretmenlerin, okul yöneticilerinin algılanan mizah tarzları konusunda benzer görüşlere sahip oldukları söylenebilir.

Kıdeme Göre Okul Yöneticilerinin Algılanan Mizah Tarzına İlişkin Bulgular

Tablo 8'de kıdem değişkenine göre okul yöneticilerinin mizah davranış düzeylerine ilişkin Kruskal Wallis testi sonuçları verilmiştir.

Tablo 8. Kıdeme Göre Okul Yöneticilerinin Algılanan Mizah Tarzları

\begin{tabular}{|c|c|c|c|c|c|c|}
\hline Boyut & Kidem & $\mathrm{n}$ & Sira Ortalaması & sd & $\mathrm{X}^{2}$ & $\mathrm{p}$ \\
\hline \multirow[t]{3}{*}{ Alayc1 } & 10 yıl ve alt & 33 & 166.48 & .76537 & 3.601 & .216 \\
\hline & $11-20 \mathrm{yll}$ & 163 & 156.77 & & & \\
\hline & 21 ve üst & 132 & 173.55 & & & \\
\hline \multirow[t]{3}{*}{ Üretici } & 10 yıl ve alt & 33 & 132.08 & 1.08763 & 5.753 & .056 \\
\hline & $11-20 \mathrm{yll}$ & 163 & 162.13 & & & \\
\hline & 21 ve üst & 132 & 175.53 & & & \\
\hline \multirow[t]{3}{*}{ Onaylayıcı } & 10 yıl ve alt & 33 & 83.17 & .94907 & 30.344 & $.000^{*}$ \\
\hline & $11-20 \mathrm{yll}$ & 163 & 164.73 & & & \\
\hline & 21 ve üst & 132 & 184.55 & & & \\
\hline \multirow[t]{3}{*}{ Reddedici } & 10 yıl ve alt & 33 & 219.79 & .83792 & 15.042 & $.001^{*}$ \\
\hline & $11-20 \mathrm{yll}$ & 163 & 152.39 & & & \\
\hline & 21 ve üst & 132 & 165.64 & & & \\
\hline \multirow[t]{3}{*}{ Mizah Olmayan } & 10 yıl ve alt & 33 & 187.92 & .94505 & 3.428 & 3.428 \\
\hline & $11-20 \mathrm{yll}$ & 163 & 167.01 & & & \\
\hline & 21 ve füst & 132 & 155.54 & & & \\
\hline
\end{tabular}

Tablo 8'e göre, öğretmenlerin k1demine göre okul yöneticilerinin onaylayıcı ve reddedici mizah tarzlarında anlamlı farklılık bulunmakta $(\mathrm{p}<.005)$ ve alayc1, üretici ve mizah olmayan tarzda ise anlamlı farklılık bulunmamaktadır. Hangi gruplar arasında anlamlı farklılık olduğunu belirlemek için gruplar arasında Mann Whitney U testi uygulanmıştır. Tablo 9'da onaylayıcı ve reddedici mizah tarzlarına İlişkin MannWhitney U Testi sonuçları verilmiştir. 
Tablo 9. Kıdem Değişkenine Göre Onaylayıcı ve Reddedici Mizah Tarzlarına İlişkin Mann-Whitney U Testi Sonuçlan

\begin{tabular}{lllllll}
\hline Boyut & Kidem & $\mathbf{n}$ & S1ra Ortalaması & Sira Toplamı & U & p \\
\hline Onaylayıc1 & 10 yıl ve alt & 33 & 56.70 & 1871.00 & 1310.000 & $.000^{*}$ \\
& $11-20$ yıl & 163 & 106.96 & 17435.00 & & \\
& 10 yıl ve alt & 33 & 43.47 & 1434.50 & 873.500 & $.000^{*}$ \\
& 21 y1 ve üst & 132 & 92.88 & 12260.50 & & \\
\hline Reddedici & 10 yıl ve alt & 33 & 132.26 & 4364.50 & 1575.500 & $.000^{*}$ \\
& $11-20$ yıl & 163 & 91.67 & 14941.50 & & \\
& 10 yıl ve alt & 33 & 104.53 & 3449.50 & 1467.500 & $.003^{*}$ \\
& 21 yıl ve üst & 132 & 77.62 & 10245.50 & & \\
\hline
\end{tabular}

Tablo 9'da belirtilen sıra ortalamaları dikkate alındığında 10 yıl ve daha az kıdeme sahip öğretmenlerin daha fazla kıdeme sahip öğretmenlere oranla okul yöneticilerinin mizah tarzlarını daha düşük düzeyde onaylayıcı algıladıkları görülmektedir. Reddedici mizah tarzında anlamlı farklilık yaratan grupların sira ortalamaları incelendiğinde ise, 10 yıl ve daha az kıdeme sahip öğretmenlerin daha fazla kıdeme sahip öğretmenlere oranla okul yöneticilerinin mizah tarzlarını daha yüksek oranda reddedici algıladıkları görülmektedir. Bu durum, 10 yıl ve daha az kıdeme sahip öğretmenlerin okul yöneticilerinin mizah tarzlarını daha fazla reddedici tarzda algıladıkları ve 10 yıl ve daha az kıdeme sahip öğretmenlerin okul yöneticilerinin mizah tarzlarını daha fazla onaylayıcı mizah tarzında algıladıkları şeklinde de yorumlanabilir. Benzer şekilde Yılmaz (2011) araştırmasında, kıdemi fazla olan okul yöneticilerinin katılımcı mizah tarzını daha fazla benimsedikleri sonucuna ulaşmıştır.

Okul yöneticilerinin algılanan mizah tarzlarının kıdem değişkeninde anlamlı farklılık gösterdiğine ilişkin bulgular ile yaş değişkenine ilişkin bulgular birbirini destekler niteliktedir. Bu durum, genç ve mesleki kıdemi daha az öğretmenler okul yöneticilerinin mizah tarzlarını daha fazla reddedici; yaşı ve kıdemi daha fazla olan öğretmenlerin ise yöneticilerinin mizah tarzlarını daha fazla onaylayıcı algıladıkları şeklinde özetlenebilir. 


\section{Okul Türüne Göre Okul Yöneticilerinin Algılanan Mizah Tarzına İlişkin Bulgular}

Tablo 10'da okul türü değişkenine göre okul yöneticilerinin mizah tarzlarına ilişkin Kruskal Wallis testi sonuçları verilmiştir.

Tablo 10. Okul türüne Göre Okul Yöneticilerinin Algılanan Mizah Tarzları

\begin{tabular}{|c|c|c|c|c|c|c|}
\hline Boyut & Okul Türü & $\mathbf{n}$ & Sira Ortalaması & sd & $\mathbf{X}^{2}$ & $\mathbf{p}$ \\
\hline \multirow[t]{3}{*}{ Alaycı } & İlkokul & 144 & 188.12 & 2 & 24.325 & $.000^{*}$ \\
\hline & Ortaokul & 102 & 152.61 & & & \\
\hline & Lise & 81 & 135.46 & & & \\
\hline \multirow[t]{3}{*}{ Üretici } & İlkokul & 144 & 162.56 & 2 & 36.446 & $.000^{*}$ \\
\hline & Ortaokul & 102 & 127.58 & & & \\
\hline & Lise & 81 & 212.41 & & & \\
\hline \multirow[t]{3}{*}{ Onaylayıc1 } & İlkokul & 144 & 160.24 & 2 & 35.181 & $.000^{*}$ \\
\hline & Ortaokul & 102 & 130.34 & & & \\
\hline & Lise & 81 & 213.07 & & & \\
\hline \multirow[t]{3}{*}{ Reddedici } & İlkokul & 144 & 182.41 & 2 & 26.463 & $.000^{*}$ \\
\hline & Ortaokul & 102 & 173.37 & & & \\
\hline & Lise & 81 & 119.48 & & & \\
\hline Mizah & İlkokul & 144 & 179.74 & 2 & 40.421 & $.000^{*}$ \\
\hline \multirow[t]{2}{*}{ Olmayan } & Ortaokul & 102 & 186.76 & & & \\
\hline & Lise & 81 & 107.36 & & & \\
\hline
\end{tabular}

Tablo 10'a göre, öğretmenlerin görev yaptıkları okul türüne göre okul yöneticilerinin mizah tarzlarında anlamlı farklılık bulunmaktadır. Hangi gruplar arasında anlamlı farklılık olduğunu belirlemek için gruplar arasında Mann Whitney U testi uygulanmıştır. Tablo 11'de okul türüne göre mizah tarzlarına İlişkin Mann-Whitney $U$ Testi sonuçları verilmiştir.

Tablo 11'de belirtilen sıra ortalamaları dikkate alındığında ilkokullarda görev yapan öğretmenlerin okul yöneticilerine ilişkin algılanan mizah tarzı, diğer okul türlerinde görev yapan öğretmenlere oranla daha fazla onaylayıcı ve üretici tarzda ve aynı zamanda da daha düşük oranda reddedici ve mizah olmayan tarz olduğu görülmektedir. Üretici mizah tarzını benimseyen yönetici, okul ortamında mizahi yönü olan bir durum yaratmakta ve bu durumu diğer insanlarla paylaşmaktadır. $\mathrm{Bu}$ bağlamda üretici mizah tarzına sahip olan yöneticiler, güldüren, eğlendiren ve çalışma ortamındaki sinerjiyi canlı tutan bireyler olarak tanımlanabilir. Ayn zamanda mizah üretebilen 
yöneticilerin okul ortamında sevilen ve beraber çalışmaktan keyif alınan yöneticiler olduğu söylenebilir.

Tablo 11. Okul Türü Değişkenine Göre Mizah Tarzlarna İlişkin Mann-Whitney U Testi Sonuçlan

\begin{tabular}{|c|c|c|c|c|c|c|}
\hline Boyut & OkulTürü & $\mathbf{n}$ & Sira Ortalaması & Sira Toplamı & $\mathbf{U}$ & p \\
\hline \multirow[t]{4}{*}{ Alaycı } & Lise & 144 & 134.94 & 19431.00 & 5697.000 & $.001^{*}$ \\
\hline & Ortaokul & 102 & 107.35 & 10950.00 & & \\
\hline & Lise & 144 & 125.68 & 18098.50 & 4005.500 & $.000^{*}$ \\
\hline & İlkokul & 81 & 90.45 & 7326.50 & & \\
\hline \multirow[t]{6}{*}{ Üretici } & Lise & 144 & 134.93 & 19429.00 & 5698.000 & $.003^{*}$ \\
\hline & Ortaokul & 102 & 107.37 & 10951.50 & & \\
\hline & Lise & 144 & 100.14 & 14419.50 & 3979.500 & $.000^{*}$ \\
\hline & İlkokul & 81 & 135.87 & 11005.50 & & \\
\hline & Ortaokul & 102 & 71.72 & 7315.00 & 2052.000 & $.000^{*}$ \\
\hline & İlkokul & 81 & 117.54 & 9521.00 & & \\
\hline \multirow[t]{6}{*}{ Onaylayıcı } & Lise & 144 & 132.53 & 19084.50 & 6043.500 & $.018^{*}$ \\
\hline & Ortaokul & 102 & 110.75 & 11296.50 & & \\
\hline & Lise & 144 & 100.21 & 14430.00 & 3990.000 & $.000^{*}$ \\
\hline & İlkokul & 81 & 135.74 & 10995.00 & & \\
\hline & Ortaokul & 102 & 71.09 & 7215.00 & 1998.000 & $.000^{*}$ \\
\hline & İlkokul & 81 & 118.33 & 9521.00 & & \\
\hline \multirow[t]{4}{*}{ Reddedici } & Lise & 144 & 129.02 & 18578.50 & 3525.500 & $.000^{*}$ \\
\hline & İlkokul & 81 & 84.52 & 6846.50 & & \\
\hline & Ortaokul & 102 & 104.75 & 10684.00 & 2831.000 & $.000^{*}$ \\
\hline & İlkokul & 81 & 75.95 & 6152.00 & & \\
\hline \multirow{4}{*}{$\begin{array}{l}\text { Mizah } \\
\text { Olmayan }\end{array}$} & Lise & 144 & 131 & 18934.50 & 3169.500 & $.000^{*}$ \\
\hline & İlkokul & 81 & 49 & 6490.50 & & \\
\hline & Ortaokul & 102 & 110.88 & 11309.50 & 2205.500 & $.000^{*}$ \\
\hline & İlkokul & 81 & 68.23 & 5526.50 & & \\
\hline
\end{tabular}

İlkokul yöneticilerinin diğer okul türlerine kıyasla daha yüksek oranda öğretmenler tarafından üretici mizah tarzına sahip algılanmaları olumlu bir husustur. Eğitim hayatına yeni başlayan yaş gurubundaki çocukların olumlu bir okul iklimine sahip öğretmen ve yöneticilerin mevcut olduğu bir okul ortamında öğrenim görmeleri öğrenci başarısını da olumlu etkileyecektir. Okul iklimi ve öğrenci başarısı birbiriyle ilişkili ve birbirlerini etkileyen iki olgudur (Özdemir, 2002). Üretici mizah tarzına sahip okul yöneticilerinin en etkili, mizahî olmayan tarza sahip okul yöneticilerinin de en etkisiz olarak algılandıklarını belirtmiştir. Okul yöneticilerinin mizah tarzı, öğretmenlerin etkililiklerinde önemli bir faktördür (Kent, 1993). 
Tablo 11'de belirtilen bir diğer bulgu da, liselerde görev yapmakta olan öğretmenlerin okul yöneticilerinin mizah tarzlarına ilişkin algilarının diğer okul türlerinde görev yapan öğretmenlere oranla daha fazla alaycı olduğu sonucuna ilişkindir. Alaycı mizah tarzı, diğer insanlara sataşmaya, onlarla herhangi bir nedenle dalga geçmeye ve onları zor durumda bırakmaya yönelik olarak kullanılan mizah tarzını ifade etmektedir (Çelik, 2014). Bu bağlamda alaycı mizah tarzının insan ilişkilerine ve dolayısıyla okul ortamındaki formal ve informal ilişkilere zarar veren bir mizah tarzıdır. Lise öğretmenlerinin okul yöneticilerini mizah tarzlarını diğer okul türlerine göre daha fazla oranda alaycı mizah tarzında algılaması, okul iklimini ve dolayısıyla okul etkililiğini olumsuz etkileyeceği bilinmektedir. Eğitimde başarılı olarak tanımlanabilecek uygulamalar, uyumlu bir biçimde birlikte çalışabilen, mutlu, güven içinde, motivasyonu yüksek öğretmen ve yöneticilerin bulunduğu okul örgütlerinde ortaya çıkmaktadır (Acarbay, 2006).

\section{Mizah Tarzlar ve Yönetim Becerileri Arasındaki İlişkiye İlişkin Bulgular}

Okul yöneticilerinin algılanan mizah tarzları ile yönetim becerileri arasındaki ilişkiyi belirlemek amacıyla korelasyon analizi yapılmıştır. Tablo 12 de okul yöneticilerinin algılanan mizah tarzları ile yönetim becerileri arasındaki ilişkinin pearson analizi sonuçları verilmiştir.

Yapılan analiz sonucunda 'Mizahi olmayan tarz' ile 'Nitelikle ilgili beceriler' arasında negatif yönlü düşük düzeyde $(r=-, 114)$ çift yönlü ve anlamlı bir ilişki $(\mathrm{p} \leq 0,01)$ bulunmuştur. Başka bir ifadeyle, katılımcı öğretmenlerin algılarına göre okul yöneticilerinin mizah olmayan tarzı arttığında 'Diğer beceriler'in azaldığı tespit edilmiştir. 'Mizahi olmayan tarz' ile 'Diğer beceriler' arasında negatif yönlü düşük düzeyde $(r=-, 125)$ çift yönlü ve anlamlı bir ilişki $(p \leq 0,01)$ bulunmuştur. Başka bir ifadeyle, katılımcı öğretmenlerin algılarına göre okul yöneticilerinin mizah olmayan tarzı arttığında diğer becerilerin azaldığı tespit edilmiştir. Quast ve Hazucha (1992) nitelik becerilerini, kişisel motivasyon, nitelikli çalışma, öğrenci başarısı, bilgilendirme ve diğer becerileri ise, sözel iletişimler, problem analizi ve karar alma şeklinde belirlemişlerdir. Bu araştırmada elde edilen sonuca göre, okul yöneticilerinin 
davranışlarında mizah kullanımını artırdıklarında nitelik beceriler ve diğer becerilerinde düşük düzeyde de olsa olumlu anlamda değişiklik meydana gelecektir. Bu bağlamda mizahı tamamen reddeden veya kullanmayan okul yöneticileri, okul ortamında olumsuz etki yaratacak ve sosyal anlamda etkileşime ve öğretmenler ile arasındaki bağlara zarar verecektir.

Tablo 12. Okul Yöneticilerinin Mizah Tarzlarn ile Yönetim Becerileri Arasındaki İlişkinin Korelasyon Değerleri

\begin{tabular}{lllllll}
\hline & & $\begin{array}{l}\text { İnisiyatif } \\
\text { Alma }\end{array}$ & $\begin{array}{l}\text { Sorumluluk } \\
\text { Alma }\end{array}$ & $\begin{array}{l}\text { Teknik } \\
\text { Beceriler }\end{array}$ & $\begin{array}{l}\text { Nitelikle } \\
\text { Ilgili }\end{array}$ & $\begin{array}{l}\text { Diğer } \\
\text { Beceriler }\end{array}$ \\
\hline Mizahi & $\mathrm{r}$ &,- 093 &,- 081 &,- 084 &,$- 114^{*}$ &,$- 125^{*}$ \\
Olmayan & $\mathrm{p}$ &, 092 &, 145 &, 129 &, 038 &, 023 \\
& $\mathrm{n}$ & 328 & 328 & 328 & 328 & 328 \\
\hline Reddedici & $\mathrm{r}$ &,$- 116^{*}$ &,- 064 &,- 055 &,- 099 &,- 108 \\
Mizah & $\mathrm{p}$ &, 035 &, 245 &, 319 &, 074 &, 051 \\
& $\mathrm{n}$ & 328 & 328 & 328 & 328 & 328 \\
\hline Onaylayıc1 & $\mathrm{r}$ &, 006 &,- 008 &,- 041 &,- 016 &, 009 \\
Mizah & $\mathrm{p}$ &, 909 &, 885 &, 457 &, 774 &, 865 \\
& $\mathrm{n}$ & 328 & 328 & 328 & 328 & 328 \\
\hline Üretici & $\mathrm{r}$ &, 037 &, 003 &,- 005 &,- 015 &, 021 \\
Mizah & $\mathrm{p}$ &, 507 &, 960 &, 929 &, 788 &, 707 \\
& $\mathrm{n}$ & 328 & 328 & 328 & 328 & 328 \\
\hline Alayc1 & $\mathrm{r}$ &,- 002 &, 005 &, 006 &, 050 &, 009 \\
Mizah & $\mathrm{p}$ &, 975 &, 930 &, 910 &, 369 &, 870 \\
& $\mathrm{n}$ & 328 & 328 & 328 & 328 & 328 \\
\hline
\end{tabular}

${ }^{*} p<0,05$ düzeyinde çift yönlü ilişki; ${ }^{* *} p<0,01$ düzeyinde çift yönlü ilişki

'Reddedici tarz' ile 'İnisiyatif alma becerileri' arasında negatif yönlü düşük düzeyde $(r=-, 116)$ çift yönlü ve anlamlı bir ilişki $(p \leq 0,01)$ bulunmuştur. Başka bir ifadeyle, katılımcı öğretmenlerin algılarına göre okul yöneticilerinin reddedici tarzı arttı̆̆ında inisiyatif alma becerilerinin azaldığ yüksek yönetim beceri düzeyinin inisiyatif alma becerisi olduğu sonucuyla beraber ele almak gerekmektedir. Bu iki sonuç beraber ele alındığında okul yöneticilerinin çalışanlar ile aralarındaki informal ilişkilerde mizahı reddedici tavır sergilemesinin, yönetim becerilerine ilişkin öğretmen algılarında farklılık yarattığını göz önünde bulundurmaları gerektiğini söylemek yanlış olmayacaktır. Aksi halde 
mizahı yönetim eylemlerinde reddeden okul yöneticisi, inisiyatif alma becerisini tam anlamıla gerçekleştiremeyeceği için çalışanları okulun hedefleri doğrultusunda yönlendirebilme konusunda eksik kalır. Reddedici mizah tarzına sahip bir yöneticinin çalışanları motive edebilmesi, çalışanlar arasındaki çatışmaları yönetebilmesi ve çalışanların da birbirleriyle etkileşim içinde olması güçleşecektir.

Determinasyon katsayıları incelendiğinde ise, reddedici mizahın insiyatif alma becerilerinin \%1'ini açıklandığ $1\left(\mathrm{r}^{2}=0.01\right)$, mizah olmayan tarzın nitelik becerilerin \% 1'ini açıklandığı $\left(\mathrm{r}^{2}=0.01\right)$, mizah olmayan tarzın diğer becerilerin \% 1 'ini açılandığı $\quad\left(r^{2}=0.01\right)$ sonucuna ulaşılmıştır.

\section{Sonuç ve Öneriler}

Sonuç olarak, olumlu mizah tarzlarını kullanan okul yöneticileri, yönetim becerilerinin boyutlarından özellikle insan ilişkilerini de kapsayan becerilerde daha başarılı olmaktadır. Okul yöneticisi ve öğretmenler arasındaki sosyal ilişkilerinin sağlıklı şekilde gelişmesinin, okul ortamına birçok açıdan olumlu yansımaları olacaktır.

Alanyazındaki araştırmalar incelendiğinde yöneticinin mizah kullanmasıyla çalışanların pozitif duyguları arasında ilişki olduğu görülmektedir (Cooper vd., 2018; Goswami vd. 2016; Wijerwadena vd., 2017). Sosyal ilişkiler kurma, arkadaşlıkları geliştirme, çatışmaları çözmede kullanılabilen olumlu mizah tarzları ile çalışanların psikolojik olarak kendilerini yeterli, dayanıklı, iyimser hissetmeleri sağlamak mümkündür.

Güleç ve Öncül'ün (2019) araştırmasında yöneticilerin katılımcı, kendini geliştirici ve kendini yıkıcı mizahının çalışanların iş yaşam kalitesini pozitif yönde etkilediği, saldırgan mizahının ise çalışanların iş yaşam kalitesini negatif yönde etkilediği sonucuna ulaşılmıştır. Yöneticilerin çalışanların iş yaşam kalitelerini arttırmak için olumlu mizah tarzlarını sergilerken olumsuz mizah tarzlarından kaçınmaları gerekmektedir.

Yöneticilerin mizah kullanımına profesyonel açıdan yaklaşılması gerekmektedir. Bulunulan şartlara göre mizah tarzının seçilmesi ve uygun ölçülerde kullanılması örgütlerde faydalı sonuçlar vermekle 
birlikte oluşabilecek olumsuz etkilerden kurtulmaya da yardımcı olacaktır. Mizahı kullanmakta zorlanan, gelişmiş mizah anlayışına sahip olmayan yöneticilerin ise sadece olumlu mizah tarzlarını ölçülü bir şekilde kullanması avantajlarına olacaktır.

$\mathrm{Bu}$ doğrultuda Bakanlık tarafından okul yöneticilerine yönelik iletişim ve mizah kullanımı ile ilgili seminerler düzenlenebilir. Aynı zamanda okul yöneticisi ile sürekli etkileşim içinde olan öğretmenlerin konuya dikkatini çekmek için okul içinde okul yöneticisinin ve öğretmenlerin birlikte katılım gösterdiği atölye çalışmaları düzenlenebilir. Yine okul yöneticilerine mizahın olumlu kullanımına ilişkin kendini yönetme yöntemlerini bilgilendirici ve kendini yönetme becerilerini geliştirmeye yönelik atölye çalışmaları yapılabilir. Okul yöneticilerine ve öğretmenlere yönelik ortaklaşa düzenlenecek seminerlerin okul iklimine etkisi daha olumlu olacaktır. Bunun yanında öğretmen adaylarının lisans eğitimleri sırasında alacakları seçmeli derslerle mesleğe başlamadan iletişim ve mizah kullanımına ilişkin farkındalıkları artırılabilir. Öğretmen yetiştirme sürecinde iletişim ile ilgili derslerin içeriği belirlenirken çeşitli alanlardan bilim uzmanlarından destek alınarak bir içerik belirlenmesinde fayda vardır. Konu ile ilgili alanyazına katkı sağlamayı düşünecek araştırmacılar benzer araştırmaları, okulun bütün paydaşlarının görüşlerini alarak, karşılaştırmalı nicel veya nitel araştırma yönteminde, her eğitim kademesinde ayrı ayrı ve farklı örneklemleri kapsayacak şekilde desenleyebilirler. 


\title{
EXTENDED ABSTRACT \\ The Relationship between School Managers' Humor Styles and Management Skills
}

\author{
Püren Akçay-Hilal Kevser Köprülü \\ İstanbul Aydın University
}

It is thought that a positive school culture and school climate, which will be supported by the right humor style, will increase the efficiency of all the stakeholders of the school, while also increasing the effectiveness of the school.

This research, which aims to reveal the relationship between the humor styles used by school administrators and their management skills within the framework of various variables, is important in terms of developing a sincere, open, reliable and moderate school climate and school culture and thus revealing the humor styles that will increase the effectiveness of the school. The aim of this research is to reveal the relationship between the humor styles used by school administrators and their management skills in the framework of dimensions and variables, in line with the opinions of teachers. Based on this main purpose, the questions to be answered in the research are as follows:

- What is the level of teachers' and school principals' perceived humor styles and management skills?

- Do the humor styles of teachers and school principals differ significantly according to the variables?

- Is there a significant relationship between teachers' perceptions of school principals' humor styles and management skills?

\section{Method}

Relational survey model, one of the quantitative research methods, was used in the research. The sample of the research consists of 328 teachers from different branches and levels, determined by simple random sampling method, working in public schools in Karamürsel District in the 2019-2020 academic year. 'Socio-demographic Information Form', 
'Management Skills Scale' (Şekerci, 2006) and 'Humor Behaviors Scale' (Cemaoloğlu, Recepoğlu, Şahin and Köktürk, 2012) were used as data collection tools in the research.

\section{Results}

As a result of the analysis, a negative and low-level $(\mathrm{r}=-.114)$ bidirectional and significant relationship $(\mathrm{p} \leq 0.01)$ was found between 'Unhumorous style' and 'Quality-related skills'. In other words, according to the perceptions of the participating teachers, when the nonhumor style of the school administrators increased, it was determined that 'Other skills' decreased. There was a low-level negative $(r=-.125)$ bidirectional and significant relationship $(\mathrm{p} \leq 0.01)$ between 'nonhumorous style' and 'Other skills'. In other words, according to the perceptions of the participating teachers, when the non-humor style of school administrators increased, other skills were found to decrease. Quast and Hazucha (1992) identified the qualification skills as personal motivation, qualified study, student success, information and other skills as verbal communication, problem analysis and decision making. According to the result obtained in this study, when school administrators increase the use of humor in their behaviors, there will be a positive change in quality skills and other skills, albeit at a low level. In this context, school administrators who completely reject or do not use humor will have a negative impact on the school environment and will damage social interaction and ties with teachers.

There was a low negative $(\mathrm{r}=-.116)$, bidirectional and significant relationship ( $\mathrm{p} \leq 0.01)$ between 'rejecting style' and 'taking initiative skills'. In other words, according to the perceptions of the participating teachers, it was determined that when the rejecting style of the school administrators increased, their ability to take initiative decreased. It is necessary to consider this result together with the conclusion that the highest perceived management skill level of school administrators is the ability to take initiative. When these two results are considered together, it would not be wrong to say that school administrators should consider that the way they reject humor in their informal relations with employees creates a difference in teachers' perceptions of management 
skills. Otherwise, the school administrator, who rejects humor in management actions, will not be able to fully realize his ability to take initiative, so he falls short of directing the employees in line with the goals of the school. It will be difficult for a manager with a rejecting humor style to motivate employees, manage conflicts between employees and interact with each other.

\section{Conclusion}

As a result, school administrators who use positive humor styles are more successful in the dimensions of management skills, especially in skills that include human relations. The healthy development of social relations between school administrators and teachers will have positive reflections on the school environment in many ways.

When the studies in the literature are examined, it is seen that there is a relationship between the manager's use of humor and the positive feelings of the employees (Cooper et al., 2018; Goswami et al. 2016; Wijerwadena et al., 2017). With positive humor styles that can be used to establish social relationships, develop friendships, and resolve conflicts, it is possible to make employees feel psychologically sufficient, resilient and optimistic.

In the study of Güleç and Öncül (2019), it was concluded that the participatory, self-enhancing and self-destructive humor of the managers positively affects the quality of work life of the employees, while the aggressive humor affects the quality of work life of the employees negatively. Managers should avoid negative humor styles while displaying positive humor styles in order to increase the quality of work life of employees.

Managers' use of humor should be approached professionally. Choosing the humor style according to the conditions and using it in appropriate measures will give beneficial results in organizations and will help to get rid of the negative effects that may occur. It will be advantageous for managers who have difficulty in using humor and do not have a developed sense of humor to use only positive humor styles in a measured way. 


\section{Kaynakça / References}

Acarbay, F. Y. (2006). Kapsaml okul iklimini değerlendirme ölçeği'nin (öğrenci formu) Türkçe dilsel eşdeğerlik güvenirlik ve geçerlik çalışması. (Yayımlanmamış Yüksek Lisans Tezi). Yeditepe Üniversitesi, İstanbul.

Akyol, M. E. (2016). Okul yöneticilerinin mizah tarzlarn ile öğretmenleri güdüleme düzeyleri arasındaki ilişki. (Yayınlanmamış Yüksek Lisans Tezi). İstanbul Aydın Üniversitesi, İstanbul.

Alan, H. ve Şen, H. T. (2016). Yöneticilerin kördüğümü: Mizah. Psikiyatri Hemşireliği Dergisi, 7(3), 152-156.

Ayduğ, D., Himmetoğlu, B. ve Bayrak, C. (2018). Okul müdürlerinin mizah tarzlarına ilişkin öğretmenlerin metaforik algıları. Eğitimde Nitel Araştırmalar Dergisi, 6(2), 108-130.

Büyüköztürk, Ş., Çakmak, E. K., Akgün, Ö. E., Karadeniz, Ş. ve Demirel, F. (2012). Bilimsel araştırma yöntemleri (Genişletilmiş 11. Bask1). Pegem Akademi.

Cemaoloğlu, N., Recepoğlu, E., Şahin, F. D. ve Köktürk, O. (2012). Mizah davranışları ölçeğinin geliştirilmesi: Geçerlik ve güvenirlik Çalışması. Türk Eğitim Bilimleri Dergisi, 10(4), 694-716.

Cooper, C. D., Kong, D. T. and Crossley, C. D. (2018). Leader humor as an interpersonal resource: Integrating three theoretical perspectives. Academy of Management Journal, 61(2), 769-796.

Cross, M. (1989). Leadership perceptions: The role of humor. (Doctoral dissertation). University of Pittsburgh.

Çelik, F. (2014). Ortaokul müdürlerinin mizah davranıslar ile öğretmenleri etkileme düzeylerine ilişkin öğretmen görüşleri Muş ili örneği, (Yayımlanmamış Yüksek Lisans Tezi). Yüzüncü Yıl Üniversitesi, Van.

Çelikten, M. ve Çelikten, Y. (2018). Okul yöneticilerinin mizah ve disiplin anlayışı. OPUS Uluslararası Toplum Araştırmaları Dergisi,8(1), 453467.

Dinç, Ü. G. ve Cemaloğlu, N. (2018). İlkokul yöneticilerinin mizah kullanma tarzları ile öğretmenlerin stres yaşama düzeyleri arasındaki ilişki ve bazı değişkenlere göre incelenmesi. Turkish Journal of Educational Studies, 5(2), 1-37. 
Edem, D. (1992). An Introduction to Education Administration in Nigeria. John Wiley.

Gamboa, J. P., Gracia, F., Ripoll, P.ve Peiró, J. M. (2009). Employability andpersonal initiative as antecedents of job satisfaction. The Spanish Journal of Psychology, 12(2), 632-640.

Goswami, A., Nair, P., Beehr, T., and Grossenbacher, M. (2016). The relationship of leaders' humor and employees' work engagement mediated by positive emotions: Moderating effect of leaders' transformational leadership style. Leadership \& Organization Development Journal, 37(8), 1083-1099.

Güleç, R. ve Öncül, M. S. (2019). Yöneticilerin mizah tarzının çalışanların iş yaşam kaliteleri üzerine etkisinde psikolojik sermayenin aracı rolü. KMÜ Sosyal ve Ekonomik Araştırmalar Dergisi, 21(37), 157-185.

Hahn, Frese, Binnewies and Schmitt (2011). Happy and proactive? The role of hedonic and eudaimonic well-being in business owners' personal initiative. Entrepreneurship Theory and Practice, 36(1), 97114. https://doi.org/10.1111/j.1540-6520.2011.00490.x

Kamble, R. R. (2011). Managerial skills for organizational performance: An analytical study. (Doctoral Dissertation). Sinhgad College of Arts and Commerce.

Karasar, N. (2012). Bilimsel araştırma yöntemi: Kavramlar-Illkeler-Teknikler. Ankara: Nobel Yayın Dağıtım.

Kent, S. H. (1993). An investigation of the relationship between humor style and effectiveness of elementary school principals as perceived by teachers in Georgia. (Doctoral Dissertation). Retrieved from ProQuest Dissertations and Theses database.

Martin, R. A., Puhlik-Doris, P. L., Gray, J. and Weir, K. (2003). Individual differences of uses of humor and their relation to psychological well-being: Development of the humor styles questionnaire. Journal of Research inPersonality, 37(1), 48-75.

Özdemir, A. (2002). Sağlıklı okul ikliminin çeşitli görünümleri ve öğrenci başarısı. Kastamonu Ĕ̆itim Dergisi, 10(1), 39-46. 
Özdemir, S. ve Recepoğlu, E. (2010). Örgütsel sağhlk ve mizah. V. Ulusal Eğitim Yönetimi Kongresi, 219-229. Antalya.

Pawlas, E.G. (1997). Vision and school culture. NASSP Bulletin 81(587),118128.

Quast, L. N. and Hazucha, J.F. (1992). The relationship between leaders' management skills and their group effectiveness. 203-207, In D.P Campbell, K.E. Clark, M.B. Clark (Eds.) Impact of leadership. Greensboro, NC: USA.

Recepoğlu, E. (2010). The effects of principals' humor on teachers' job satisfaction. Education and Science, 33(150), 74-86.

Recepoğlu, E. (2011). Öğretmen algılarına göre okul müdürlerinin mizah tarzları ile öğretim liderliği davranışları ve okulun örgütsel sağhlğı arasındaki ilişki. (Yayınlanmamış Doktora Tezi). Gazi Üniversitesi, Ankara.

Recepoğlu, E. ve Özdemir, S. (2012). Okul müdürlerinin mizah tarzları ile öğretim liderliği davranışları arasındaki ilişki. İnönü Üniversitesi Eğitim Fakültesi Dergisi, 13(3), 24-42.

Reynolds, D., Teddlie, C., Creemers, B., Scheerens, J. and Townsend, T. (2000). An introduction to school effectiveness research. (In C. Teddlie and D. Reynolds (eds.). The international handbook of school effectiveness research. Falmer Press: London.

Searle, B. J. (2008). Does personal initiative training work as a stress management intervention? Journal of Occupational Health Psychology, 13(3),259-270. https://doi.org/10.1037/10768998.13.3.259.

Şekerci, M. (2006). İlköğretim okulu yöneticilerinin yönetim becerileri ile grup etkililiği arasındaki ilişki. (Yayınlanmamış Yüksek Lisans Tezi). Çanakkale Onsekiz Mart Üniversitesi, Çanakkale.

Şenel, T. ve Buluç, B. (2016). İlkokullarda okul iklimi ile okul etkililiği arasındaki ilişki. TÜBAV Bilim Dergisi, 9(4), 1-12.

Taris, T. V. and Wielenga-Meier, E. G. A. (2010). Workers' personal initiative as a moderator of the relations between job characteristics and well-being. Psychological Reports, 107(1), 255-64. https://doi.org/10.2466/pr0.107.1.255-264 
Vickers, P. C. (2004). The use of humor as a leadership tool by Florida public school principals. (Doctoral dissertation). University of Central Florida.

Wijewardena, N., Härtel, C. E. and Samaratunge, R. (2017). Using humor and boosting emotions: An affect-based study of managerial humor, employees' emotions and psychological capital. Human Relations, 70(11), 1316-1341.

Williams, R. A. and Clouse, R. W. (1991). Humor as a management technique: Its impact on school culture and climate. (Report No. EA 023 388) (Nashville, TN, Metropolitan Nashville-Davidson County Schools) (ERIC Document Reproduction Service No. ED $337866)$.

Xue, X. and Wang, Z. M. (2009). Study on the influential process of burnout on personal initiative. Chinese journal of applied psychology, Retrieved from http://en.cnki.com.cn/Article en/CJFDTotalYXNX200901004.htm.

Yılmaz, K. (2011). Okul yöneticilerinin mizah tarzlarının çeşitli değişkenler açısından incelenmesi. İnönü Üniversitesi Ĕ̆itim Fakültesi Dergisi, 12(1), 27-44.

Ziegler, V., Boardman, G. and Thomas, M. (1985). Humor, leadership, and school climate. The Clearing House, 58(8), 346-348.

\section{Kaynakça Bilgisi / Citation Information}

Akçay, P. ve Köprülü, H. K. (2021). Okul yöneticilerinin mizah tarzları ile yönetim becerileri arasındaki ilişki. OPUS-Uluslararası Toplum Araştırmaları Dergisi, 18(Yönetim ve Organizasyon Özel Saysı), 1308-1336. DOI: 10.26466/opus.890396 